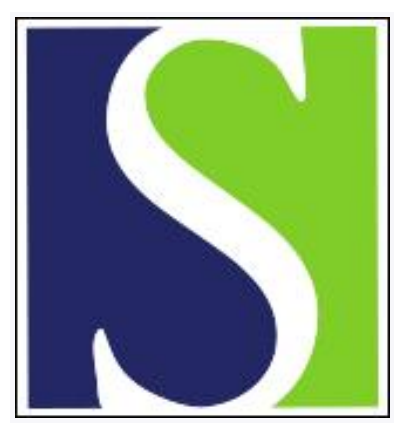

Scand J Work Environ Health 1986;12(6):603-608

https://doi.org/10.5271/sjweh.2096

Issue date: Dec 1986

Urinary elimination of acetone in experimental and occupational exposure.

by Pezzagno G, Imbriani M, Ghittori S, Capodaglio E, Huang J

This article in PubMed: www.ncbi.nlm.nih.gov/pubmed/3823809

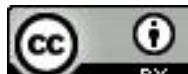




\title{
Urinary elimination of acetone in experimental and occupational exposure
}

\author{
by Giulio Pezzagno, MD, ${ }^{1}$ Marcello Imbriani, MD, ${ }^{1}$ Sergio Ghittori, BS, ${ }^{2}$ Emanuele Capodaglio, MD, ${ }^{1}$ \\ Jinxiang Huang, $M D^{3}$
}

\begin{abstract}
PEZZAGNO G, IMBRIANI M, GHITTORI S, CAPODAGLIO E, HUANG J. Urinary elimination of acetone in experimental and occupational exposure. Scand J Work Environ Health 12 (1986) 603-608. Fifteen volunteers were exposed to an acetone vapor concentration of $964-8610 \mu \mathrm{mol} / \mathrm{m}^{3}\left(56-500 \mathrm{mg} / \mathrm{m}^{3}\right)$ for $2-4 \mathrm{~h}$ in an exposure chamber. Ten subjects were at rest during the exposure, and five were exposed at alternate rest and light physical exercise. Subsequently 104 workers occupationally exposed to acetone were studied. The relative uptake averaged about $53 \%$, and the ratio of the alveolar concentration to the environmental concentration averaged about 0.28 . Both for the experimentally exposed subjects and the occupationally exposed workers the urinary acetone concentration showed a linear relationship to the corresponding environmental time-weighted average concentration. A linear equation also existed between urinary concentrations and the amounts of acetone absorbed. The findings enable a consideration of the urinary concentration of the unaltered acetone as an appropriate exposure indicator and the proposal of a "biological equivalent threshold" to be used in the field of biological monitoring.
\end{abstract}

Key terms: biological monitoring, urinalysis.

Acetone is a highly volatile solvent and widely used in industry. Its uptake at the workplace occurs mainly through the lungs. It is extremely soluble in blood and water $(13,20,22,25,28,32)$, but its fat and oil solubility is much lower $(13,28)$. General studies have been devoted to its uptake, its distribution in body tissues, and its elimination $(1,2,3,34)$. The postexposure elimination of acetone via the lung is about $20 \%$; small amounts of acetone (approximately $1 \%$ ) are eliminated as such in the urine (34). The metabolized amount excreted in the urine exceeds $75 \%$ (34). The biological indicators proposed thus far for the evaluation of occupational exposure to acetone are its concentration in alveolar or mixed-expired air $(7,8,21)$ and its concentration in venous or arterial capillary blood $(8,34)$. Urinary formic acid values have also been proposed $(6,19)$.

Recently close relationships between environmental and urinary concentrations of some solvents and anesthetics have been found $(12,15,16,23,26,27,29,30$, 31). These results suggest that the solvent or anesthetic concentration in a sample of urine produced during the exposure period could be considered an appropriate indicator of exposure levels. In the case of acetone however the correct interpretation of the results could

\footnotetext{
${ }^{1}$ Second Section of Occupational Health, Department of Preventive, Occupational and Community Medicine, University of Pavia, Pavia, Italy.

2 "Clinica del Lavoro" Foundation, Medical Center of Pavia, Pavia, Italy.

${ }^{3}$ Institute of Health, Chinese Academy of Preventive Medicine, Beijing, China. Visiting researcher and grantee of "Fondazione Clinica del Lavoro" di Pavia.
}

Reprint requests to: Professor G Pezzagno, II Sezione di Medicina del Lavoro, Via S Boezio 24, I-27100 Pavia, Italy. be complicated by the amount of endogenously produced and eliminated substance (10), mainly if the metabolic acetone elimination is not constant (33).

The main aim of our study was to verify the relationship between the urinary acetone concentrations and the corresponding mean environmental concentrations in the breathing zone or the amounts absorbed. We also aimed to derive an acetone "biological equivalent limit" [urinary concentration corresponding to the environmental threshold limit value (TLV) proposed by the American Conference of Governmental Industrial Hygienists (4) to be used in the field of biological monitoring].

\section{Subjects and experimental design}

The experiments were performed either with healthy volunteers in a laboratory (stage 1) or directly on work premises with groups of subjects occupationally exposed (stage 2). Details of the experimental design and analytical methods were described in a previous report (25).

In short, in stage 115 subjects, 13 men and 2 women (24 to 52 years of age), were exposed to acetone in an open exposure chamber. The acetone vapors were produced with a dynamic diffusion system previously described (14). The acetone concentrations (analyzed every 5 min by means of a gas cromatograph-mass selective detector system) differed from subject to subject but were kept constant during each exposure period (table 1).

The total group was divided into three "fivesubject" subgroups as follows: subgroup 1: 2-h ex- 
Table 1. Single values of the time-weighted average of the environmental concentration $\left(\mathrm{C}_{\bar{j}}\right)$, uptake $(U)$ of acetone during exposure $\left[U(\mu \mathrm{mol})=\dot{V} \cdot\left(C_{\bar{T}}-C_{\bar{E}}\right) \cdot t / 1000\right.$ if $\dot{V}$ is expressed as liter per minute and $C_{\bar{j}}$ and $C_{\bar{E}}$ as micromoles per cubic meter], the venous blood concentration $\left(\mathrm{C}_{\mathrm{v}}\right)$ (blood withdrawn immediately after the end of exposure), and the urinary concentration $\left(\mathrm{C}_{\overrightarrow{\mathrm{u}}}\right)$ (urine sampled immediately after exposure). The last column shows the regression equation relating $\mathrm{C}_{\overline{\mathrm{u}}}, \mathrm{C}_{\mathrm{v}}$ and $\mathrm{C}_{\mathrm{i}}$. The relationship between $C_{\bar{u}}$ and $U$ is $C_{\bar{u}}=0.0142 \times U+14.85(r=0.82 ; N=15)$.

\begin{tabular}{|c|c|c|c|c|c|}
\hline Subgroups & $\underset{\left(\mu \mathrm{mol} / \mathrm{m}^{3}\right)}{\mathrm{C}_{\bar{j}}}$ & $\underset{(\mu \mathrm{mol})}{\mathrm{U}}$ & $\underset{(\mu \mathrm{mol} / \mathrm{l})}{\mathrm{C}_{\mathrm{v}}}$ & $\underset{(\mu \mathrm{mol} / \mathrm{l})}{\mathrm{C}_{\bar{u}^{-}}}$ & Regression equations \\
\hline \multicolumn{6}{|l|}{ First } \\
\hline Subject 1 & 1894 & 1015 & 27.8 & 32.8 & \multirow[t]{2}{*}{$C_{\bar{u}}=0.0125 \times C_{\bar{i}}+5.87(r=0.98)$} \\
\hline Subject 2 & 3134 & 1102 & 42.4 & 36.5 & \\
\hline Subject 3 & 7025 & 3250 & 104.3 & 95.7 & \\
\hline Subject 4 & 1722 & 499 & 21.6 & 29.5 & \multirow[t]{2}{*}{$C_{v}=0.0152 \times C_{\bar{i}}-1.9(r=0.99)$} \\
\hline Subject 5 & 3115 & 1773 & 51.3 & 46.6 & \\
\hline \multicolumn{6}{|l|}{ Second } \\
\hline Subject 6 & 2307 & 2600 & 35.5 & 39.3 & \multirow[t]{2}{*}{$C_{\bar{u}}=0.0145 \times C_{\bar{\jmath}}+6.97(r=0.96)$} \\
\hline Subject 7 & 4167 & 3771 & 42.9 & 65.2 & \\
\hline Subject 8 & 5.269 & 4546 & 119.3 & 83.7 & \\
\hline Subject 9 & 6612 & 4787 & 124.3 & 117.2 & \multirow[t]{2}{*}{$C_{v}=0.0182 \times C_{\bar{i}}-7.5(r=0.87)$} \\
\hline Subject 10 & 7749 & 6733 & 117.9 & 109.5 & \\
\hline \multicolumn{6}{|l|}{ Third } \\
\hline Subject 11 & 2238 & 3530 & 48.5 & 36.5 & \multirow[t]{2}{*}{$\mathrm{C}_{\overline{\mathrm{u}}}=0.018 \times \mathrm{C}_{\overline{\mathrm{j}}}-4.52(r=0.99)$} \\
\hline Subject 12 & 3667 & 6078 & 83.7 & 48.7 & \\
\hline Subject 13 & 964 & 912 & 21.1 & 18.8 & \multirow{3}{*}{$\mathrm{C}_{\mathrm{v}}=0.0196 \times \mathrm{C}_{\overline{\mathrm{i}}}+5.8(\mathrm{r}=0.99)$} \\
\hline Subject 14 & 8610 & 8162 & 172.8 & 155.2 & \\
\hline Subject 15 & 2308 & 2657 & 52.2 & 39.5 & \\
\hline
\end{tabular}

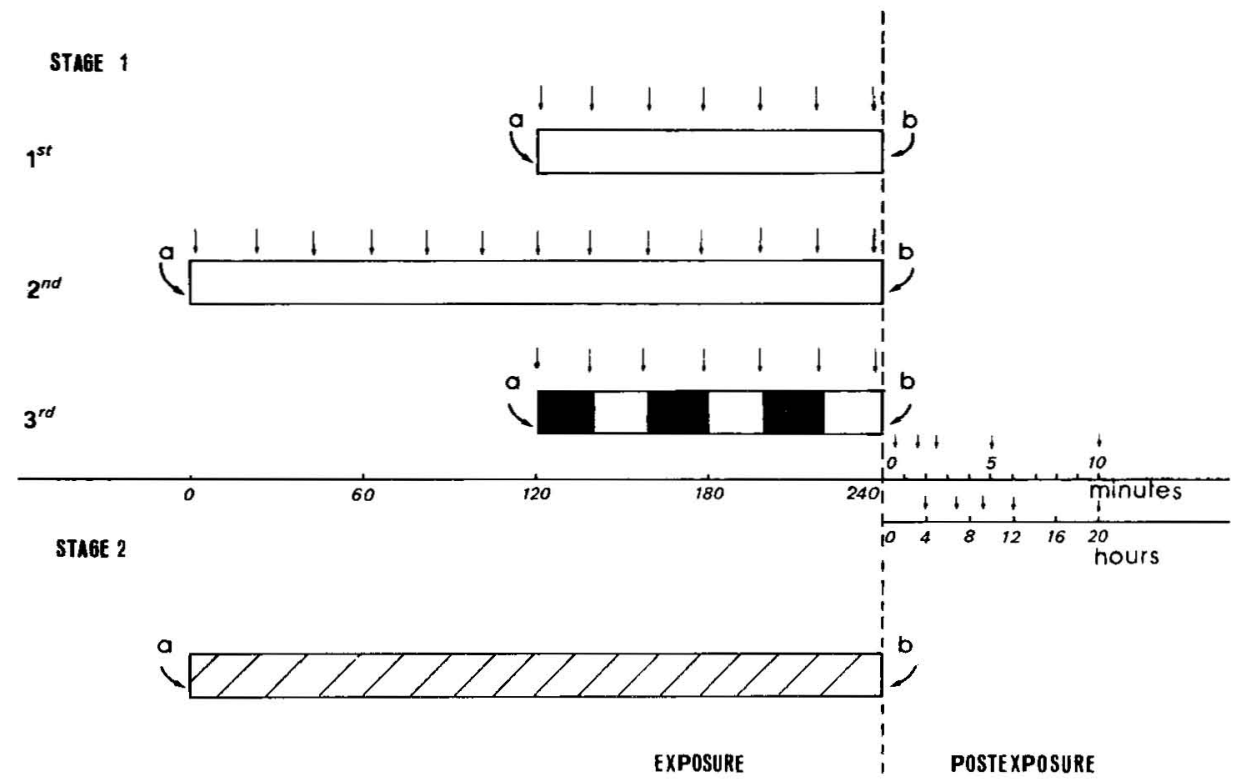

Figure 1. Scheme applied during the experimental chamber exposure (stage 1) and during occupational exposure (stage 2) to acetone. 1st, 2nd, and 3rd refer to the three subgroups considered. (See the text.) The arrows during the exposure period indicate the collecting times of environmental $\left(\mathrm{C}_{\bar{j}}\right)$, alveolar $\left(\mathrm{C}_{\mathrm{A}}\right)$, mixed-expired air $\left(\mathrm{C}_{\overline{\mathrm{E}}}\right)$, and pulmonary ventilation $\left(\mathrm{V}^{\mathrm{V}}\right)$ measurements; arrows in the postexposure period refer to collecting times of alveolar samples (minutes) and urine samples (hours). [a = the beginning of the exposure (emptying the bladder) and $b=$ the end of exposure (collection of urine and blood samples]

posure at rest; subgroup 2: 4-h exposure at rest; subgroup 3: 2-h exposure alternating light physical exercise and rest $(20 \mathrm{~min}$ at a work load of $50 \mathrm{~W}$ on a bicycle ergometer followed by 20 min at rest, three times each during $2 \mathrm{~h}$ of exposure) (figure 1 , stage 1 ). The subjects entered the exposure chamber immediately after they emptied their bladders. During the exposure, samples of chamber air $\left(C_{1}\right)$, alveolar air $\left(C_{A}\right)$, and mixed-expired air $\left(\mathrm{C}_{\overline{\mathrm{E}}}\right)$ were collected at regular inter- vals of $20 \mathrm{~min}$. Pulmonary ventilation (i) was measured for $5 \mathrm{~min}$ simultaneously with the expired air sampling. The apparatus employed for the $C_{A}, C_{\bar{E}}$, and $\dot{V}$ measurements has already been described earlier (26). Immediately after the end of the exposure, a venous blood sample was taken from a brachial vein, and a urine sample was collected, the necessary precautions being taken (26). During the postexposure period the alveolar air sampling continued for $10 \mathrm{~min}$. 
Additional samples of the urine were collected 4, 7, 9,12 , and $20 \mathrm{~h}$ after the end of the exposure (figure 1).

Stage 2 involved 104 subjects (average age 43 years) employed in three factories with different exposure levels. The physical demand of the work involved was practically the same in the three factories. There was one paint factory, one plastics factory (with styrene as an additional pollutant), and one artificial fiber factory (where acetone was the only pollutant). Shifts were 8 h daily $(0800-1600$, with a half-hour lunch break at 1200). Urine was collected from all the subjects at 0800 and 1200 , a total of 208 samples being taken (figure 1). In addition the individual time-weighted environmental concentration of acetone in the breathing zone was measured during the $4 \mathrm{~h}$ of exposure by means of personal passive samplers (18).

\section{Methods}

The urinary $\left(\mathrm{C}_{\overline{\mathrm{u}}}\right)$ and venous blood $\left(\mathrm{C}_{\mathrm{v}}\right)$ concentrations of acetone were measured by means of a gas chromatograph (GC) (Hewlett-Packard 5880 A) plus a mass selective detector (MSD) (Hewlett-Packard $5970 \mathrm{~A})$. The analytical conditions for the GC were: cross-linked column $5 \%$ phenyl methyl silicone (internal diameter $0.2 \mathrm{~mm}$, length $25 \mathrm{~m}$ ), column temperature $30^{\circ} \mathrm{C}$, carrier gas helium with a flow rate of $1 \mathrm{ml} / \mathrm{min}$, retention time of acetone $1 \mathrm{~min} 42 \mathrm{~s}$, and sampler volume (kept at $37^{\circ} \mathrm{C}$ ) $0.5 \mathrm{ml}$. The analytical conditions for the MSD were: monitored ion 43, dwell time $100 \mathrm{~ms}$, single-ion-mass window time 0.1 AMU (amount mass unit), and electromultiplier voltage 2000 $\mathrm{V}$. The lower limit of detection of acetone for the MSD was $1.4 \mu \mathrm{mol} / 1$. The following equation was used for obtaining the urinary $\left(\mathrm{C}_{\overline{\mathrm{u}}}\right)$ and the venous blood $\left(\mathrm{C}_{\mathrm{v}}\right)$ concentrations:

$$
\mathrm{C}_{\overline{\mathrm{u}}} \text { or } \mathrm{C}_{\mathrm{v}}=\left(\mathrm{X} / \mathrm{V}_{\mathrm{I}}\right)\left[\lambda\left(\mathrm{V}_{\mathrm{I}} / \mathrm{V}_{\mathrm{a}}\right)+1\right) \text {, }
$$

where $V_{1}$ is the volume of the urine $(10 \mathrm{ml})$ or blood $(5 \mathrm{ml}), \mathrm{V}_{\mathrm{a}}$ is the air head-space volume in the vials used, $\mathrm{X}$ is the acetone concentration in the head space after equilibration between the two phases, and $\lambda$ is the acetone Ostwald partition coefficient urine:air or blood:air at $37^{\circ} \mathrm{C}$, corresponding respectively to 350 (17) and 265 (25).

The alveolar $\left(C_{A}\right)$ and mixed-expired air $\left(C_{\bar{E}}\right)$ measurements of acetone were made with the same GC and MSD and under the same analytical conditions used for the blood and urine samples.

The activated charcoal of the passive dosimeters used in stage 2 to measure the time-weighted average (TWA) of the environmental concentration of acetone in the breathing zone $\left(\mathrm{C}_{\overline{\mathrm{I}}}\right)$ was desorbed with $5 \mathrm{ml}$ of carbon disulfide and then kept at room temperature $\left(20^{\circ} \mathrm{C}\right)$ for $1 \mathrm{~h}$ and periodically shaken (18). Last, $0.5 \mu \mathrm{l}$ of the desorption liquid was injected into the GC-MSD unit, the working conditions being as described previously.

\section{Results}

\section{Stage 1}

The average concentration in the exposure chamber $\left(C_{\overline{1}}\right)$ ranged from 964 to $8610 \mu \mathrm{mol} / \mathrm{m}^{3}$ (56 to 500 $\mathrm{mg} / \mathrm{m}^{3}$ ) for the different subjects (table 1). During the exposure the chosen values for each subject were maintained at relatively constant levels [coefficient of variation (mean value: standard deviation) $9 \%$ ]. The mean relative uptake $(R)$, measured from $C_{\bar{I}}$ and $C_{\bar{E}}(R=$ $1-\mathrm{C}_{\overline{\mathrm{E}}} / \mathrm{C}_{\overline{\mathrm{I}}}$ ) was 0.54 (SD 0.04) at rest and 0.53 (SD 0.06 ) during light physical exercise; the same parameter obtained from the $C_{A}: C_{I}$ ratio and the proposed equation $\left(R=-0.72 \times C_{A}: C_{I}+74.6\right)$ (2) had practically the same value, ranging from 0.53 to 0.59 . The mean pulmonary ventilation $(\dot{V})$ under standard conditions $\left(0^{\circ} \mathrm{C}, 103 \mathrm{kPa}\right.$, dry) was 7.3 (SD 1.14) $1 / \mathrm{min}$ for the subjects at rest and 17.6 (SD 1.55) $1 / \mathrm{min}$ for those who performed light physical exercise. The mean values of the alveolar clearance followed the changes in $\dot{\mathrm{V}}\left(\mathrm{Cl}_{\mathrm{A}}=\dot{\mathrm{V}} \times \mathrm{R}\right)$ and were found to be 3.92 (SD 0.52) $1 / \mathrm{min}$ for the subjects at rest and 9.63 (SD $0.35) \mathrm{l} / \mathrm{min}$ for those who performed light physical exercise. The amounts absorbed from each subject during the exposure time $(\mathrm{t})$ [total uptake $(\mathrm{U})=$ $\left.\dot{\mathrm{V}}\left(\mathrm{C}_{\mathrm{I}}-\mathrm{C}_{\overline{\mathrm{E}}}\right) \mathrm{t}\right]$ ranged from 499 to $8162 \mu \mathrm{mol}$ (29 to $474 \mathrm{mg}$ ) (table 1).

The TWA environmental concentration $\left(C_{\overline{\mathrm{I}}}\right)$ and the urinary $\left(C_{\bar{u}}\right)$ and blood $\left(C_{v}\right)$ concentrations obtained for the three "five-subject" subgroups at the end of exposure are shown in table 1, together with the total uptake (U) and the regression equations.

The $\mathrm{C}_{\overline{\mathrm{u}}}$ values displayed a statistically significant linear relationship with the corresponding $C_{\bar{I}}$ values (table 1). A close relationship was also found between $\mathrm{C}_{\overline{\mathrm{u}}}$ and the amounts of acetone absorbed (U, $\left.\mu \mathrm{mol}\right)$ (figure 2). The $y$ intercept is in accordance with the average urinary endogenous acetone concentration obtained for the 15 subjects under study [13.1 (SD = 10.8) $\mu \mathrm{mol} / \mathrm{l}$ ]; none of these volunteers had previously been exposed to acetone. When the endogenous

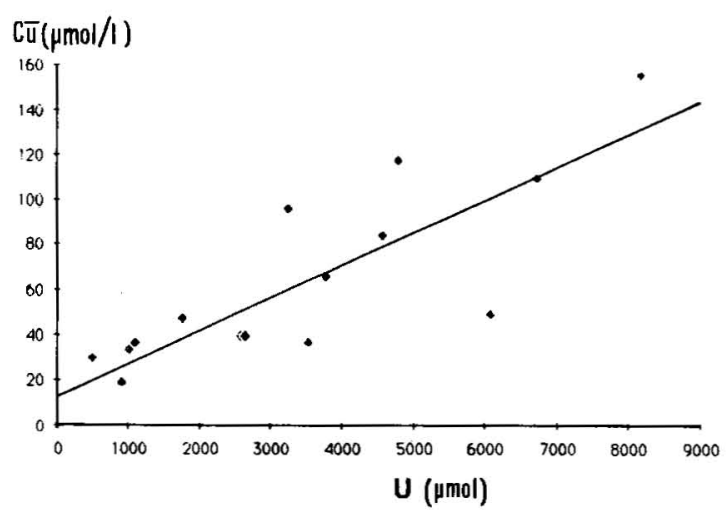

Figure 2. Scatter diagram relating the amount of acetone absorbed (U) by each subject experimentally exposed and the corresponding urinary concentration $\left(\mathrm{C}_{\bar{u}}\right)$. The regression line $\left(C_{\bar{u}}=0.0142 \times U+14.85 ; N=15, r=0.82\right)$ is also shown. 

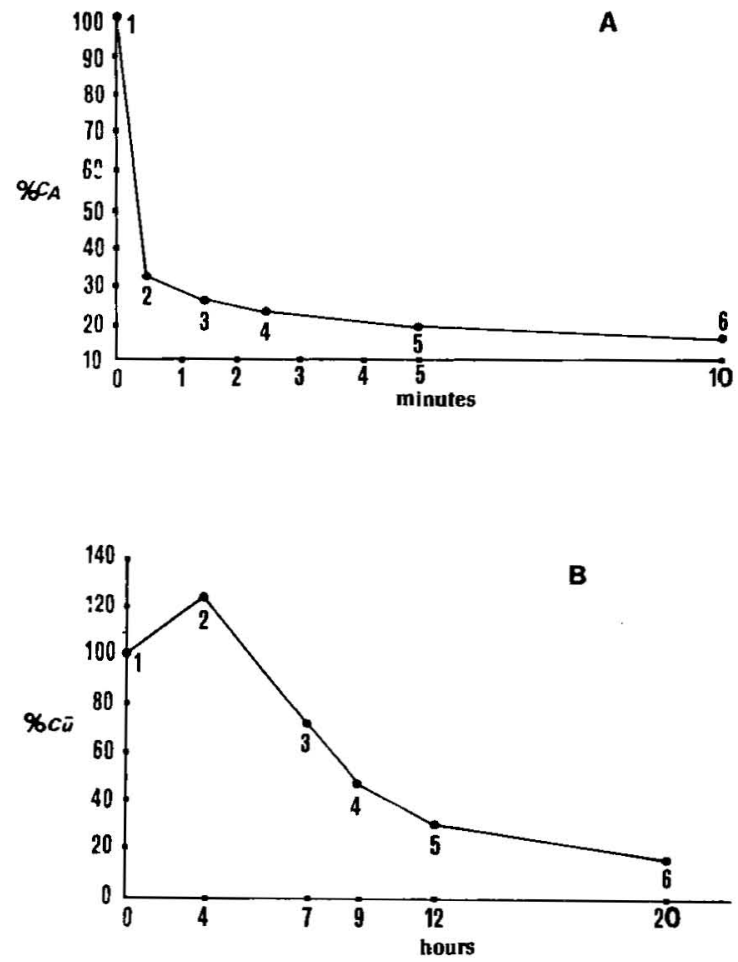

Figure 3. Decrease of alveolar concentration (A) of acetone in the course of the postexposure period. The concentration values are expressed as the percentage of the end-exposure ones. The mean alveolar concentration $\left(C_{A}\right)$ of the entire group of subjects was $1059 \mu \mathrm{mol} / \mathrm{m}^{3}$. During the first $10 \mathrm{~min}$ after the end of exposure the $C$ values at $0.5,1.5,2.5,5$ and $10 \mathrm{~min}$ were $341,284,246,198$, and $162 \mu \mathrm{mol} / \mathrm{m}^{3}$, respectively, corresponding to a decrease of $67.8,73.2,76.8,81.3$, and $84.7 \%$ respectively, of the average end-exposure value. The urinary concentration (B) of acetone in the course of the first $20 \mathrm{~h}$ following the end of exposure is also shown. The mean coef ficients of variation were $45 \%$ for the alveolar acetone concentration $\left(\mathrm{C}_{A}\right)$ and $32 \%$ for urinary acetone concentration $\left(\mathrm{C}_{\vec{u}}\right)$.

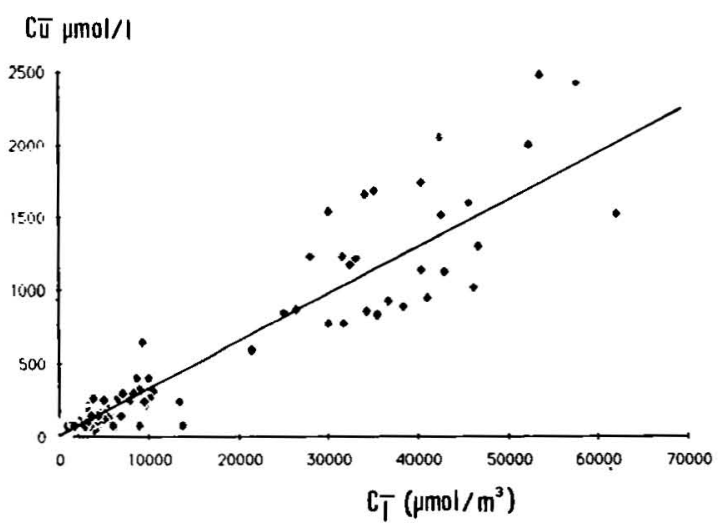

Figure 4. Scatter diagram relating the time-weighted average of the environmental concentration (in the breathing zone) $\left(\mathrm{C}_{i}\right)$ and the urinary concentration $\left(\mathrm{C}_{\bar{u}}\right)$ of acetone (urine collected after $4 \mathrm{~h}$ of exposure) for the occupationally exposed subjects. The regression line $\left(C_{\bar{u}}=0.033 \times C_{\bar{T}}-0.005 ; r=0.94 ; N=\right.$ 104) is also shown. acetone concentration is subtracted, the equation becomes:

$$
\Delta \mathrm{C}_{\overline{\mathrm{u}}}=0.0145 \times \mathrm{U}-0.024,
$$

where $\mathrm{U}$ is expressed in micromoles and $\Delta \mathrm{C}_{\overline{\mathrm{u}}}$ in micromoles per liter.

A significant relationship was also found between the instantaneous acetone environmental concentration $\left(C_{1}\right)$ and the alveolar concentration of acetone $\left(C_{A}\right)$ [correlation coefficient $(r)=0.91$ ] $(\mathrm{N}=92)$ :

$$
\mathrm{C}_{\mathrm{I}}=3.60 \times \mathrm{C}_{\mathrm{A}}+182.5 \text {, }
$$

where $C_{I}$ and $C_{A}$ are expressed in micromoles per cubic meter.

A close relationship between the blood concentration of acetone $\left(\mathrm{C}_{\mathrm{v}}\right)$ and the corresponding $\mathrm{C}_{\overline{\mathrm{I}}}$ also existed (table 1).

The mean alveolar concentration $\left(\mathrm{C}_{\mathrm{A}}\right)$ of the entire group of subjects was 1059 (range 120-2 927) $\mu \mathrm{mol} / \mathrm{m}^{3}$. During the first $10 \mathrm{~min}$ after the end of the exposure the $C_{A}$ values decreased as shown in figure $3 \mathrm{~A}$. The $\mathrm{C}_{\overline{\mathrm{u}}}$ trend in the course of the $20 \mathrm{~h}$ following the end of exposure is also shown in figure $3 \mathrm{~B}$.

\section{Stage 2}

A close relationship between the TWA environmental concentration $\left(\mathrm{C}_{\overline{\mathrm{I}}}\right)$ and the corresponding urinary concentration $\left(\mathrm{C}_{\overline{\mathrm{n}}}\right)$ also existed for the group of subjects occupationally exposed to acetone vapor $(r=0.94)$ $(\mathrm{N}=104)$ (figure 4):

$$
\mathrm{C}_{\overline{\mathrm{u}}}=0.033 \times \mathrm{C}_{\overline{\mathrm{I}}}-0.005 \text {, }
$$

where $C_{\overline{\mathrm{u}}}$ is expressed in micromoles per liter and $\mathrm{C}_{\overline{\mathrm{I}}}$ in micromoles per cubic meter. The equation obtained after the preexposure acetone concentration values were subtracted from the postexposure ones is the following $(\mathrm{r}=0.91)(\mathrm{N}=104)$ :

$$
\Delta \mathrm{C}_{\overline{\mathrm{u}}}=0.0189 \times \mathrm{C}_{\overline{\mathrm{I}}}+4.06 \text {. }
$$

\section{Discussion}

The starting values for the relative uptake $(R)$ and relative alveolar concentration $\left(\mathrm{C}_{\mathrm{A}}: \mathrm{C}_{\overline{\mathrm{I}}}\right)$ of acetone should depend on its blood:air partition coefficient ( $\lambda$ blood : air). Our results $\left(\mathrm{R}=0.55, \mathrm{C}_{\mathrm{A}}: \mathrm{C}_{\overline{\mathrm{I}}}=0.28\right)$ practically confirm the data of previous investigations $(7,11,34,35)$; another report gives instead a lower value (24). Because of the very high $\lambda$ blood: air value, theoretically the expected values of $R$ should be higher (and consequently the $\mathrm{C}_{\mathrm{A}}: \mathrm{C}_{\overline{\mathrm{I}}}$ values lower). It is possible that the relatively low fat : air partition coefficient plays an important role as a limiting factor in the transfer of acetone through the alveolar capillary membrane (34). In addition the exchanges with the tissues surrounding the respiratory dead space (due to the high solubility of acetone) and, consequently, the contamination of the alveolar samples could be an 
explanation (9). The $R$ value and $C_{A}: C_{\bar{I}}$ ratio trends during exposure depend on the possibility of the biological tissues to store solvent and on the rate of its biotransformation. Our results, in accordance with those already published (34), show a practically constant value for $R$ and the $C_{A}: C_{\bar{I}}$ ratio throughout the entire exposure time (therefore at least up to the end of the fourth hour) in the range of the environmental concentration values chosen $\left(964-8610 \mu \mathrm{mol} / \mathrm{m}^{3}\right.$ or $\left.56-500 \mathrm{mg} / \mathrm{m}^{3}\right)$. Such behavior permits us to exclude the saturation of the biological compartments as a cause for the low $\mathrm{R}$ acetone values.

The main aim of the present research was, however, to determine whether a linear relationship existed between the acetone exposure levels [expressed either as the TWA environmental concentration $\left(\mathrm{C}_{\overline{\mathrm{I}}}\right)$ or as amounts of acetone absorbed $(\mathrm{U})$ ] and the acetone urinary concentrations $\left(C_{\bar{u}}\right)$. Experimentally (stage 1$)$ we found that the slope of the regression line was different in the three subgroups considered. In the first subgroup the regression coefficient was 0.0125 ; in the second it was 0.0145 ; finally in the third it was the highest, ie, 0.018 (table 1). The difference in slope between the equation obtained after 2 and $4 \mathrm{~h}$ of exposure at rest (first and second subgroups, respectively) probably means that a continuous increase of acetone in arterial blood [as referred to by Wigaeus et al (34)] and therefore in urine occurs from the beginning of exposure and up to $4 \mathrm{~h}$. The urinary instantaneous concentrations $\left(\mathrm{C}_{\mathrm{u}}\right)$ should in fact be proportional to the arterial concentrations $\left(C_{a}\right)$, with a proportional coefficient corresponding to the $\lambda$ blood : urine value, on the assumption that the exchange of solvent between the arterial blood and urine occurs after simple partition in accordance with Henry's law. Only when a constant $C_{a}$ value has been reached, should the slope of the regression lines be independent of the exposure time, the instantaneous $C_{\bar{u}}$ values then being constant.

The greater slope of the regression line in the third subgroup was instead due to the work load. Under such conditions, $\mathrm{R}$ values being equal, the amounts of acetone absorbed are obviously larger (depending on pulmonary ventilation). Greater $\mathrm{C}_{\mathrm{a}}$ values are therefore reached $(2,34)$, consequently greater $C_{\bar{u}}$ values as well. The trend of alveolar $\left(\mathrm{C}_{\mathrm{A}}\right)$ and urinary $\left(\mathrm{C}_{\overrightarrow{\mathrm{u}}}\right)$ concentrations in the course of $10 \mathrm{~min}$ and $20 \mathrm{~h}$ after exposure, respectively, is shown in figures $3 \mathrm{~A}$ and $\mathrm{B}$.

The $\mathrm{C}_{\overline{\mathrm{u}}}$ value measured $4 \mathrm{~h}$ after the end of exposure was always higher than that measured immediately after exposure (figure $3 \mathrm{~B}$ ). The explanation for such apparently paradoxical behavior, which has been seen also by others (34), could be connected with a slow urinary decrease during the postexposure period.

A close relationship between the TWA environmental concentration in the breathing zone $\left(\mathrm{C}_{\overline{\mathrm{I}}}\right)$ and the urinary concentration $\left(\mathrm{C}_{\overline{\mathrm{u}}}\right)$ of acetone in samples collected after $4 \mathrm{~h}$ of exposure also existed for the group of occupationally exposed subjects $(r=0.94)$ (figure 4). The regression coefficient was 0.033 . This value is higher than the one obtained in the third subgroup of experimental exposures. The urine samples of the occupationally exposed subjects were collected after $4 \mathrm{~h}$ of exposure, and the work load may have been greater than in the third subgroup.

The urinary concentration $\left(\mathrm{C}_{\overline{\mathrm{u}}}\right)$ corresponding to the TWA TLV (4) $\left(30651 \mu \mathrm{mol} / \mathrm{m}^{3}\right.$ or $\left.1780 \mathrm{mg} / \mathrm{m}^{3}\right)$ is $1000 \mu \mathrm{mol} / 1(58 \mathrm{mg} / \mathrm{l})$ and the corresponding biological exposure limit ( $95 \%$ lower confidence limit of the regression line) is $930 \mu \mathrm{mol} / \mathrm{l}(54 \mathrm{mg} / \mathrm{l})$. Unlike other solvents studied from that point of view $(12,15$, $16,23,26,27,29$ ), acetone is a normal component of the biological compartments. In the present study the endogenous acetone concentration in urine averaged $13.1 \mu \mathrm{mol} / \mathrm{l}$ with a high standard deviation (10.8 $\mu \mathrm{mol} / \mathrm{l})$. It is also well known that heavy exercise increases the endogenous amounts of acetone eliminated $(21,33)$. This possibility could represent a hindrance to a correct interpretation of the exposure. Under conditions of light work load, however, this phenomenon should not play a significant role. In five volunteers not exposed to acetone and performing light physical exercise, the urinary concentrations of acetone did not increase significantly because of the effort (table 2).

The biological indicators proposed thus far for occupational exposure to acetone are the acetone concentration in alveolar air $(5,7,8)$, the acetone concentration in venous or arterial capillary blood $(5,8$, 34 ), and the urinary excretion rate of formic acid (6). The results obtained both experimentally from volunteers exposed in an exposure chamber and from groups of subjects occupationally exposed enable us to use also the acetone urinary concentration.

The urinary acetone concentration is a weighted value indicating a natural weighting over time of the rather fast partitioning between air and arterial blood and between arterial blood and urine (the bladder serving as a collecting and mixing vessel); so the $\mathrm{C}_{\overline{\mathrm{u}}}$-weighted values measured from samples of urine produced throughout the exposure, and collected at the end of it, provide an appropriate index of the magnitude of exposure during the production time of urine. Moreover, the situations of higher uptake of acetone (the environmental concentration being equal) by subjects working under different work loads are clearly detected by the $C_{\overline{\mathrm{u}}}$ values (figure 2). In addition it

Table 2. Average values of the endogenous acetone urinary concentration ( $\mu \mathrm{mol} / \mathrm{l})$ of five volunteers at rest (first day) and performing light physical exercise (second day).

\begin{tabular}{lrrrrrrr}
\hline & \multicolumn{7}{c}{ Time } \\
\cline { 2 - 8 } & 0800 & 1000 & 1200 & 1400 & 1800 & 2000 & 2300 \\
\cline { 2 - 8 } & & & & & & & \\
$\begin{array}{l}\text { First day } \\
\text { (without effort) }\end{array}$ & 34.9 & 24.1 & 19.8 & 22.8 & 23.5 & 24.1 & 26.8 \\
$\quad \begin{array}{l}\text { Mean } \\
\text { SD }\end{array}$ & 16.1 & 14.4 & 10.5 & 13.2 & 16.4 & 14.4 & 14.8 \\
$\begin{array}{l}\text { Second day } \\
\text { (with effort) }\end{array}$ & & & & & & & \\
$\quad \begin{array}{l}\text { Mean } \\
\text { SD }\end{array}$ & 15.3 & 16.1 & 11.3 & 14.9 & 14.8 & 20.6 & 18.6 \\
\hline
\end{tabular}


should be pointed out that the unchanged acetone urinary concentration should not be affected either by other solvents interfering with each other in the biotransformation rate or by the presence of common metabolites. Last, the method is simple, quickly performed, and noninvasive.

\section{Acknowledgments}

This work was supported by "Fondazione Clinica del Lavoro" di Pavia, IRCCS (finalized project).

\section{References}

1. Åstrand I. Uptake of solvents in the blood and tissues of man: A review. Scand J Work Environ Health 1 (1975) 199-218.

2. Astrand I. Effect of physical exercise on uptake, distribution and elimination of vapors in man. In: FiserovaBergerova V, ed. Modeling of inhalation exposure to vapors: Uptake, distribution and elimination. Volume II. CRC Press, Boca Raton, FL 1983, pp 107-130.

3. Âstrand I. Uptake of solvents from the lungs. Br J Ind Med 42 (1985) 217-218.

4. American Conference of Governmental Industrial Hygienists. Exposure indices proposed by ACGIH for 1984-85. Cincinnati, $\mathrm{OH} 1984$.

5. Baselt RC. Acetone. In: Biological monitoring methods for industrial chemicals. Biomedical Publications, Davis, CA 1980, pp 8-10.

6. Baumann K, Angerer J. Untersuchungen zur Frage der beruflichen Losungsmittelbelastung mit Aceton. In: AW Gentner Verlag. Verhandlung der Deutschen Gesellschaft fur Arbeitsmedizin e.V. Stuttgart 1979, pp 403-409.

7. Brugnone F, Perbellini L, Gaffuri E, Apostoli P. Biomonitoring of industrial solvent exposures in workers' alveolar air. Int Arch Occup Environ Health 47 (1980) 245-261.

8. Brugnone F, Perbellini L, Grigolini L, Apostoli P. Solvent exposure in a shoe upper factory: I n-Hexane and acetone concentration in alveolar and environmental air and in blood. Int Arch Occup Environ Health 42 (1978) $51-62$.

9. Cander L, Forster RE. Determination of parenchymal tissue volume and pulmonary capillary blood flow. J Appl Physiol 14 (1959) 541-551.

10. Di Vincenzo GD, Yanno FJ, Astill BD. Exposure of man and dog to low concentrations of acetone vapor. Am Ind Hyg Assoc J 34 (1973) 329-336.

11. Egle JL. Retention of inhaled acetone and ammonia in the dog. Am Ind Hyg Assoc J 34 (1973) 533-539.

12. Ferry DG, Temple WA, Mc Queen EG. Methanol monitoring. Int Arch Occup Environ Health 47 (1980) $155-163$.

13. Fiserova-Bergerova V. Gases and their solubility: A review of fundamentals. In: Fiserova-Bergerova V, ed. Modeling of inhalation exposure to vapors: Uptake, distribution and elimination. Volume I. CRC Press, Boca Raton, FL 1983, pp 3-28.

14. Ghittori S, Imbriani M, Pezzagno G. Un sistema aperto per esposizione a concentrazioni note e controllate di aeriformi. G Ital Med Lav 5 (1983) 251-254.

15. Imbriani M, Ghittori S, Pezzagno G, Capodaglio E. nHexane urine elimination and weighted exposure concentration. Int Arch Occup Environ Health 55 (1984) $33-41$.
16. Imbriani M, Ghittori S, Pezzagno G, Capodaglio E. Toluene and styrene in urine as biological exposure indexes. Ann Am Conf Ind Hyg 12 (1985) 351-355.

17. Imbriani M, Ghittori S, Pezzagno G, Capodaglio E. Urine/air partition coefficients for some industrially important substances. G Ital Med Lav (in press).

18. Lauterberger WJ, Kring CV, Morello JA. Theory of passive monitors. In: Kelley WD, ed. Dosimetry for chemical and physical agents. Ann Am Conf Ind Hyg 1 (1981) 91-99.

19. Lauwerys RR. Industrial chemical exposure: Guidelines for biological monitoring. Biomedical Publications, Davis, CA 1983, pp 104-105.

20. Lindquist T. Partition coefficient of blood/air and water/air for some commonly used solvents. In: Proceeding of the International Conference of Occupational Health, Prague, 1977. Prague, 1977, pp 165-166.

21. Manolis A. The diagnostic potential of breath analysis Clin Chem 29 (1983) 5-15.

22. Maroni M, Foà V. Il coefficiente di ripartizione sangue/ aria in vitro come possibile test predittivo dell'assorbimento di solventi. In: Istituto Italiano di Medicina Sociale. Proceeding of the $39^{\circ}$ Congresso Nazionale della Societá Italiano di Medicina del Lavoro, Fiuggi-Terme, 16-18 settembre 1976. Volume 1. Roma 1976, pp 497-503.

23. Miyasaka M, Kumai M, Koizumi A, Watanabe T, Kurasako $\mathrm{K}$, Sato $\mathrm{K}$, Iheda $\mathrm{M}$. Biological monitoring of occupational exposure to methyl ethyl ketone by means of urinalysis for methyl ethyl ketone itself. Int Arch Occup Environ Health 50 (1982) 131-137.

24. Nomiyama $\mathbf{K}$, Nomiyama $\mathbf{H}$. Respiratory retention, uptake and excretion of organic solvents in man. Int Arch Arbeitsmed 32 (1974) 75-83.

25. Pezzagno G, Ghittori S, Imbriani M, Capodaglio E. La misura dei coefficienti di solubilità degli aeriformi nel sangue. Nota II: I solventi di largo impiego industriale. G Ital Med Lav 5 (1983) 49-63.

26. Pezzagno G, Ghittori S, Imbriani M, Capodaglio E. Urinary elimination of styrene in experimental and occupational exposure. Scand J Work Environ Health 11 (1985) 371-379.

27. Pezzagno G, Imbriani M, Ghittori S, Capodaglio E. Il significato della eliminazione urinaria di toluolo come indicatore di esposizione. Med Lav 76 (1985) 44-60.

28. Sato A, Nakajima T. Partition coefficients of some aromatic hydrocarbons and ketones in water, blood and oil Br J Ind Med 36 (1979) 231-234.

29. Sedivec V, Mraz M, Flek J. Biological monitoring of persons exposed to methanol vapours. Int Arch Occup Environ Health 48 (1981) 257-279.

30. Sonander $M$, Sterqvist $O$, Nilsson $K$. Exposure to trace amounts of nitrous oxide. Br J Anaesth 55 (1983) 12251229.

31. Sonander $M$, Sterqvist $\mathrm{O}$, Nilsson $\mathrm{K}$. Urinary $\mathrm{N}_{2} \mathrm{O}$ as a measure of biological exposure to nitrous oxide anaesthetic contamination. Ann Occup Hyg 27 (1983) 73-79.

32. Wagner PD, Naumann PF, Laravuso RB. Simultaneous measurement of eight foreign gases in blood by gas chromatography. J Appl Physiol 36 (1974) 600-605.

33. Walther A, Neumann G. The course of acetone elimination in the expiratory air in cyclists prior to, during and after a specific laboratory stress. Acta Biol Med Ger 22 (1969) $117-121$.

34. Wigaeus E, Holm S, Astrand I. Exposure to acetone: Uptake and elimination in man. Scand J Work Environ Health 7 (1981) 84-94.

35. Wigaeus E, Lof A, Byfalt Nordqvist M. Uptake, distribution, metabolism, and elimination of styrene in man: A comparison between single exposure and coexposure with acetone. $\mathrm{Br} \mathrm{J}$ Ind Med 41 (1984) 539-546.

Received for publication: 28 May 1986 